\title{
Analysis of the government regulations on COVID-19 pandemics in Indonesia: implementation and challenges
}

\author{
Benny Hidayat ${ }^{1 *}$, Ade Suzana Putri $^{2}$, Taufika Ophiyandri ${ }^{1}$, Bambang Istijono ${ }^{1}$, Dilanthi Amaratunga ${ }^{3}$, Richard \\ Haigh $^{3}$, and Asitha de Silva ${ }^{3}$ \\ ${ }^{1}$ Civil Engineering Dept., Faculty of Engineering, Andalas University, Padang, West Sumatra, Indonesia \\ ${ }^{2}$ Faculty of Public Health, Andalas University. Padang, West Sumatra, Indonesia \\ ${ }^{3}$ Global Disaster Resilience Centre, University of Huddersfield, United Kingdom
}

\begin{abstract}
COVID-19 started in China and then spread to other countries. The Indonesian government officially announced the first case of COVID-19 on 2nd March 2020. Previously, on 4th February, the Ministry of Health issued a Decree of the Minister of Health number HK.01.07 of 2020 regarding "Determination of Novel Coronavirus Infection (2019-Ncov Infection) as a Disease That Can Cause Outbreaks And Efforts to Overcome it". WHO then declared COVID-19 as a pandemic on 11th March 2021. After that, the central government issued various regulations related to the handling of COVID-19. This paper aims to study the regulations issued by the Indonesian government regarding the handling of COVID-19. The research method uses a content analysis method using nVivo software. The study results show that the regulations are quantified, consisting of $30 \%$ related to social, $10 \%$ related to the budget, $25 \%$ related to health, $20 \%$ related to COVID-19 handling organizations, and $15 \%$ related to economic recovery. This paper also presents the challenges related to the implementation of these regulations
\end{abstract}

\section{Introduction}

The World Health Organization (WHO) on 11th March 2020 declared the coronavirus outbreak or COVID-19 as a global pandemic. This outbreak was initially discovered in Wuhan (China) and then spread to other countries. The determination of the status of this pandemic is due to the rapid and widespread to areas far from the center of the outbreak. With this pandemic status, WHO asks all countries to increase their response to the COVID-19 emergency.

In modern human history, this ongoing outbreak of COVID-19 is unprecedented. WHO has declared COVID-19 as a pandemic, but the factors that cause, vulnerability, and impact of COVID-19 are not only limited to health factors This pandemic has had a very hard impact on people who are already in a vulnerable condition, such as women, children, migrant workers, and people with disabilities. This pandemic is an example of systemic risk where the existing hazard not only harms parts of the system but also has the potential to fail for all systems. The normal approach that the government has taken so far for disasters does not seem to be able to answer the challenges in handling the COVID-19 pandemic. It is particularly important to better align the prevention and response efforts of health ministries and disaster management authorities, from national to local.
COVID-19 has underlined that response mechanisms require much strengthening. As this pandemic is unprecedented, most countries do not have practical experience in handling events resulting from a combination of natural hazards and biological hazards.

The COVID-19 pandemic has been declared a national disaster in Indonesia. Its massive impact, particularly on health and socioeconomic aspects, requires quick and effective responses from every level of government to administer the pandemic control measures and to enhance community capacity to cope with the pandemic impact. Some literature explores the government responses from countries at the regional or national level [1-4]. However, rarely are discussing the preparedness at the local level, particularly in decentralized government countries, and exploring how COVID-19 pandemic enhance the local government to take into account the epidemic or pandemic as an important biological hazard in their contingency policy and embedding health into their disaster risk management.

Padang city is the capital of the West Sumatra Province of Indonesia and has a population of around one million people. It is situated on the very flat liquefiable ground, and $50 \%$ of residents live in tsunami inundation areas. Indonesia is one of the most vulnerable countries to disasters globally, frequently exposed to various hazards. Indonesia has a high risk of flooding, as more than $60 \%$

* Corresponding author: bennyhidayat@eng.unand.ac.id 
of Indonesia's districts are exposed to flood hazards. Indonesia also faces high seismic, tsunami, and volcanic risk, as situated in the Pacific Ring of Fire with 127 active volcanoes. With approximately five major events per year, Padang is a metropolitan area that is one of the most prone to geophysical disasters in Indonesia. The disasters that occurred in Indonesia not only had an impact on humans but also had an impact on the economy. Living in hazardous areas, having limited financial resources, and limited access to basic services make the poor and vulnerable the most affected by disasters.

Like many other cities across the globe, Padang could not escape from the current COVID-19 pandemic. As of 28th December 2020, in Indonesia, there were a total of 765,350 confirmed cases with 22,734 deaths [5]. The numbers increased significantly to $3,967,048$ confirmed cases and 125,342 deaths per 21st August 2021 [6]. In Padang, there are 40,016 total confirmed cases and 511 total deaths as of 22nd August 2021 [7]. A significant increase of new cases and deaths were notified in June and July 2021, and Padang has been identified as one of the cities with the highest level of risk by the Ministry of Health [8].

With the condition of the city of Padang, which is very prone to disasters, and the condition of the ongoing COVID pandemic, the need for disaster risk reduction policies that embed health factors appears. As an initial step to achieve this, a study is carried out on how the handling of COVID-19 is still ongoing. This paper aims to examine the government's response in handling COVID-19 in the form of reviewing key documents regarding regulations related to COVID-19. Problems and challenges were also identified in the implementation of these regulations. Then a study was conducted on the implementation of regulations at the local government level, taking the case in the city of Padang.

\section{Research Method}

This paper is an initial part of research entitled 'Embedding COVID-19 Preparedness Into Local Disaster Risk Reduction, which was carried out by a team of researchers from Universitas Andalas and Huddersfield University. This paper is an initial study conducted by the team from Universitas Andalas.

At this initial stage, a study was conducted on the response that had been carried out by the Indonesian government in dealing with COVID-19, in the form of issuing regulations at the central government and local government levels. Also identified are the obstacles and challenges in implementing these regulations.

The study in this paper uses a literature review by applying the content analysis method from regulatory documents and research paper documents related to COVID-19 in Indonesia. Regulatory documents related to COVID-19 issued by the government are traced from the National Legal Documentation and Information Network (JDIHN) system with the website address at https://jdihn.go.id/. Meanwhile, research papers on COVID-19 were traced from the Garuda Portal, a portal containing articles published in journals in Indonesia.
Because this is about COVID-19, the selected paper was published in 2020 and 2021.

The regulatory and research papers are then downloaded in the file. Then using the nVivo software (Fig.1), content analysis was carried out on these papers. This nVivo software will help determine the themes of problems in implementing regulations related to COVID-19. Additional data and information were also obtained by conducting interviews with key officials in the Padang city government and the Padang City Regional Disaster Management Agency (BPBD).

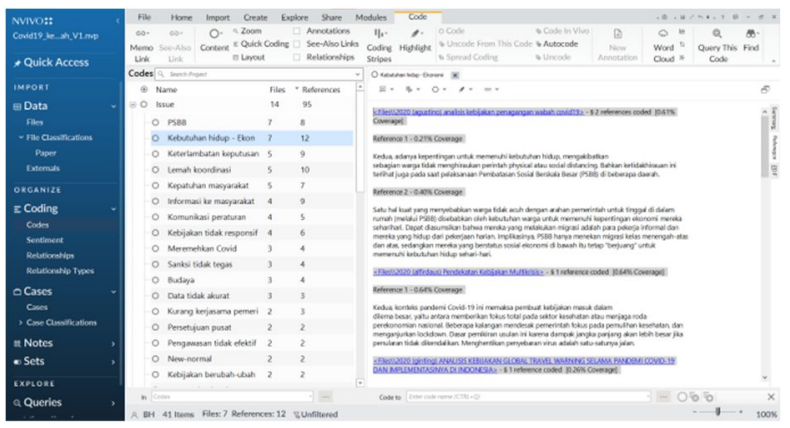

Fig. 1. nVivo software to analyze regulations and papers

\section{Results and Discussions}

The government officially announced the first case of COVID-19 on 2nd March 2020. Previously, on 4th February, the Ministry of Health issued a Decree of the Minister of Health number HK.01.07 of 2020 regarding "Determination of Novel Coronavirus Infection (2019Ncov Infection) as a Disease That Can Cause Outbreaks And Efforts to Overcome it". WHO then declared COVID-19 a pandemic on 11th March 2021.

After that, the central government issued various regulations related to COVID-19 (see figure 2). On 20th March, the President issued Presidential Instruction Number 4 of 2020 regarding "refocusing of activities, reallocation of budgets and procurement of goods and services in the context of accelerating the handling of Corona Virus Disease 2019 (COVID-19)". This instruction calls for prioritizing the use of existing budget allocations for activities that accelerate the handling of COVID-19 in ministries, institutions, and government units. The Presidential Instruction also aims to accelerate the procurement of goods and services related to the handling of COVID.

On 20th March 2020, Presidential Decree No. 9 of 2020 was also issued regarding the Task Force for the Acceleration of Handling COVID-19. This decision improves the previous decision, increasing the membership of the task force from various institutions, because the spread of COVID-19 has spread and has an impact on social, economic, economic, health and welfare aspects of the people, including WHO has declared COVID-19 a pandemic.

At the end of March, the government again issued several regulations. Law Number 2020 concerning state financial policies and financial stability for handling COVID-19. Government Regulation Number 21 of 2020 
was also issued regarding Large-Scale Social Restrictions (PSBB) in the context of accelerating the handling of COVID-19. Also, on the same date, Presidential Decree No. 11 of 2020 concerning the Determination of the COVID-19 Public Health Emergency was issued, which declared COVID-19 as a public health emergency that must be taken care of. At the same time, Presidential Regulation Number 52 of 2020 was issued, which assigned the Ministry of Public Works and Public Housing to carry out the construction of observation and shelter facilities in the fight against COVID-19 along with public infrastructure, facilities, and utilities on Galang Island, Batam City, Riau Islands Province.

Following up on PP No. 21 of 2020 concerning PSBB, the Ministry of Health issued guidelines for large-scale social restrictions (abbreviated in Indonesian as PSBB) with health regulation number 9 of 2020 on 3rd April 2020. Large-Scale Social Restrictions are restrictions on certain activities of residents in an area suspected of being infected with Corona Virus Disease. Implementation of Large-Scale Social Restrictions includes school and workplace holidays, restrictions on religious activities, restrictions on activities in public places or facilities, restrictions on social and cultural activities, restrictions on transportation modes, and restrictions on other activities specifically related to defense and security aspects.

Then on 13th April 2020, Presidential Decree No. 12 of 2020 was issued regarding the Determination of NonNatural Disasters that Cause Corona Virus Disease 2019 (COVID-19) as a National Disaster. The consideration is that this non-natural disaster caused by the spread of COVID-19 has impacted increasing the number of victims and property losses, expanding the coverage area affected by the disaster, and having implications for broad socioeconomic aspects in Indonesia. This presidential decree also orders governors, regents, and mayors as the Chair of the Task Force for the Acceleration of Handling
COVID-19 in the regions; in setting policies in their respective regions, they must pay attention to the policies of the Central Government.

In May and the following month, the government issued a series of government regulations in the economic field related to COVID-19. On 11th May, Government Regulation No. 23 of 2020 was issued for the National Economic Recovery Program (PEN). This program is a series of activities for the recovery of the national economy, which is part of the state financial policy implemented by the government to accelerate the handling of the pandemic and face threats that endanger the national economy and financial system stability and save the national economy. On 10th June, PP No. 29 of 2020 was issued regarding income tax facilities in the context of handling COVID-19. In August, following the issuance of PP No. 49 of 2020 regarding the adjustment of contributions for the social security program for workers during the non-natural disaster of COVID-19.

In September 2020, a series of regulations related to the COVID-19 vaccine was issued. Presidential Decree No. 18 of 2020, dated 3rd September 2020, regarding the acceleration of the development of the COVID-19 vaccine. Then on 5th October 2020, Presidential Regulation No. 99 of 2020 was issued regarding the procurement and implementation of vaccinations in response to the COVID-19 pandemic. Then on 9th February 2021, Presidential Regulation number 14 of 2021 was issued regarding the procurement and implementation of vaccinations, amending PP Number 99 of 2020.

Of the various regulations related to COVID-19 issued by the central government, if grouped based on the theme of the regulation, the quantification consists of $30 \%$ related to social society, $10 \%$ related to the budget, $25 \%$ related to health, $20 \%$ related to organizations handling COVID-19, and $15 \%$ related to economic recovery.

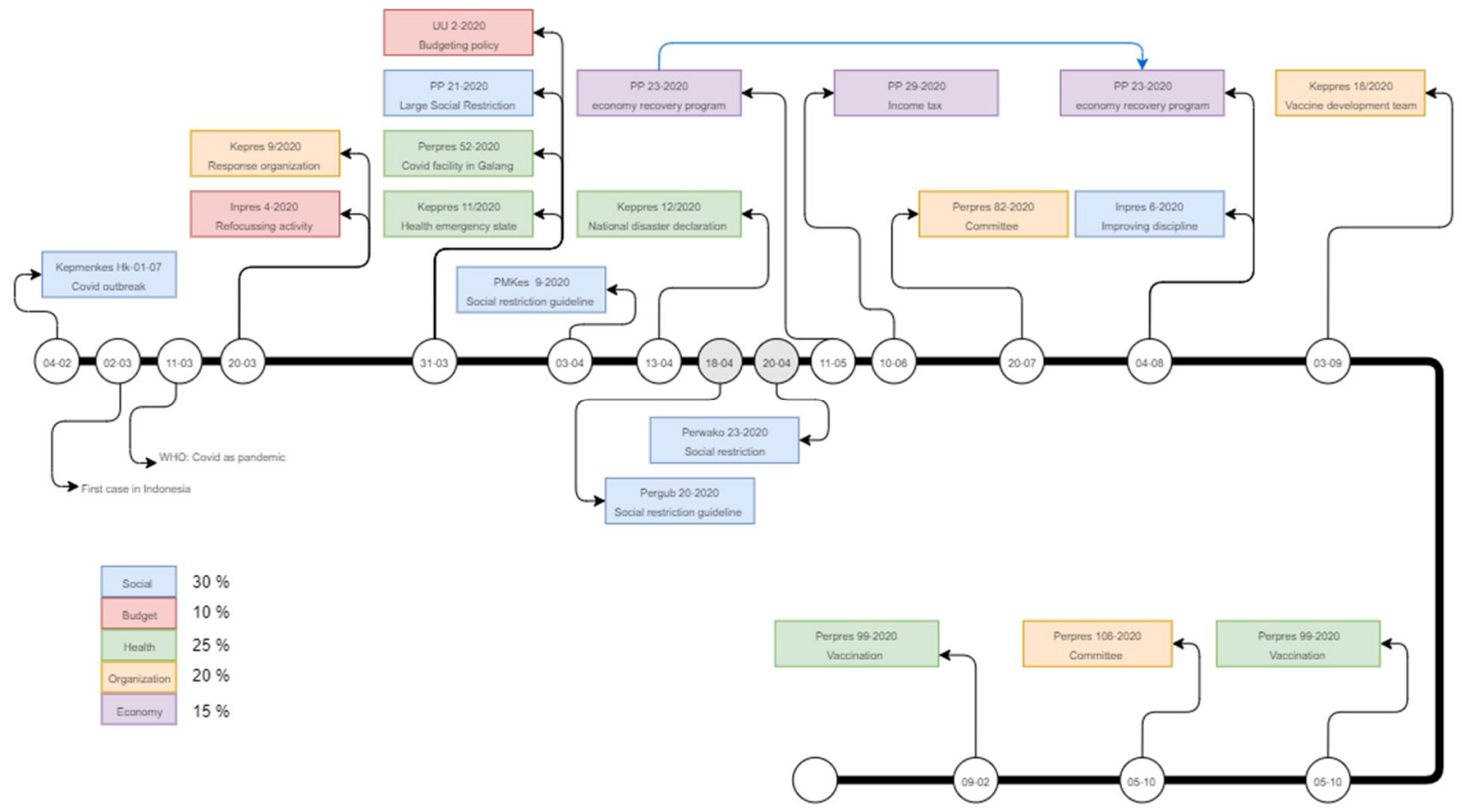

Fig. 2. Timeline of COVID-19 related regulations 


\subsection{Challenges}

The first case of COVID-19 in Indonesia was announced by the government on 2nd March 2020. After that, the government issued a series of regulations related to the handling of COVID-19, forming an organization to handle COVID-19, regulations related to social society, related to health, related to the economy, and related to budgeting.

One government policy that is directly related to the spread of the COVID virus is to implement a large-scale social restriction (called PSBB, Pembatasan Sosial Berskala Besar). The implementation of PSBB is based on epidemiological considerations, the magnitude of the threat, effectiveness, resource support, operational technical, economic, social, cultural, and security considerations. This policy is in the form of Government Regulation Number 21 of 2020 concerning PSBB in the Context of Accelerating Handling of COVID-19. PSBB is a restriction on certain activities of residents in an area suspected of being infected with COVID-19 to prevent the possible spread of the virus. Furthermore, through the Regulation of the Minister of Health Number 9 of 2020, the government issued guidelines for implementing PSBB to reduce the number of COVID-19 cases that have increased.

The implementation of this PSBB is one of the government regulations that are directly related to the general public. The government banned the holding of mass activities and crowds, and companies were closed and schools and campuses. Offices were asked to lay off their employees. Ports, airports, stations, terminals, and other transportation infrastructure are restricted. Business places such as hotels, shopping malls, and tourist attractions, and sports stadiums are closed. Houses of worship are also not allowed to hold mass activities that invite crowds.

In the implementation of these government regulations, there are several issues and challenges in their implementation. Several issues and challenges can be identified from the content analysis of journal articles regarding COVID-19 in Indonesia. Issues and challenges in implementing this regulation are interrelated.

\subsubsection{The government's initial response was slow.}

At the beginning of the COVID-19 outbreak, the government was considered slow in responding [9], [10]. The President issued Presidential Decree Number 7 of 2020 concerning the Task Force for the Acceleration of Handling the 2019 Corona Virus Disease after 11 days of announcing the first case in Indonesia. On 20th March 2020, the President issued Presidential Decree No. 9 of 2020, which gave the governor the authority to direct and evaluate the handling of COVID-19 in their respective regions.

\subsubsection{The economic needs of the community.}

The implementation of the regulations is faced with the community's basic needs, and many people violate the rules to stay at home (during PSBB) because of the pressure of household economic needs. Most of those affected are informal workers who depend on their daily income. Generally, they have no savings, and when their movement is restricted, then their income becomes nonexistent.

One strong thing that causes residents to be indifferent to the government's directive to stay at home (through PSBB) is the need for residents to fulfill their daily economic interests. It can be assumed that those who migrate are informal workers and those who make a living from daily work. The implication is that the PSBB only suppresses the migration of the middle-upper and upper classes, while those with lower socioeconomic status continue to struggle to meet their daily needs.

Data from the Central Statistics Agency (BPS) recorded that formal workers in Indonesia amounted to $55,272,968$ people while informal workers numbered $74,093,224$. This large number of informal workers experience social vulnerability because they are faced with the choice to comply with government advice or maintain family economic resilience [11].

The research of Mujani and Irvani [12] noted that there was a relationship between income and community compliance. They noted that residents who used to work before COVID-19 tended to violate PSBB. Residents who have a negative attitude towards the PSBB are more likely to have educational backgrounds and lower incomes. Because people's incomes are low, they cannot live without working regularly outside the home unless they get social security while staying at home and not working.

\subsubsection{Weak coordination.}

Weak coordination between stakeholders is also a problem in controlling the spread of the coronavirus in Indonesia [13]. The government system in Indonesia is a unitary state, placing the central government as the main stakeholder in terms of disasters, both natural and nonnatural disasters, including health. The government system in Indonesia also recognizes the concept of regional autonomy, which mandates that regional governments can carry out all affairs except foreign policy, defense, security, judicial, monetary and fiscal, and religion.

The lack of transparency of the central government in providing valid data regarding COVID-19 has forced several local governments to lock down or quarantine their territories independently. The central government opposed this decision because the regional quarantine decision was the authority of the central government. This example shows the weak coordination between the central and local governments, which has caused the spread of COVID-19 in almost all provinces in Indonesia to move quickly. The "authority of affairs" issue between the central and local governments was also a debate in the early days of COVID-19 attacking Indonesia.

\subsubsection{Community non-compliance and sanctions.}

Many people have not complied with the regulations made by the government, such as the PSBB. In addition to meeting economic needs, people are also bored staying 
at home for a long time. People are also fed up with the restrictions on work and activities and choose to keep doing their routines.

In the implementation, officers are also considered less alert, have unclear sanctions, and have low discipline, which is why the rules are not successfully implemented. This is also exacerbated by the lack of oversight of the implementation of regulations.

Government firmness is also needed in implementing these regulations, in the form of sanctions for those who violate them, so that people become more obedient. The government must have the courage to impose sanctions on citizens who do not comply with the government's appeal or direction. These sanctions not only deter people but also make people consent to do things regulated by the government.

\subsubsection{Culture and politics.}

The implementation of regulations related to COVID-19 is also faced with Indonesian culture. The implementation of PBBB becomes ineffective when the cultural activity is being done. For example, 'mudik' or traveling to the place of origin is considered something that cannot be abandoned. Religious activities are also something that cannot be abandoned, so that restrictions on movement by the government are also in some places ineffective.

Mujani \& Irvani's research [12] also found that their political preferences also influenced people's compliance with COVID-19 regulations. People who support government parties tend to agree to regulations, and on the other hand, people who are not pro to government parties tend to not comply with government regulations.

\subsubsection{Information to the public.}

Communications conveyed by the government regarding the handling of COVID-19 are less effective, including the lack of accurate data and information submitted by the government to the public, the lack of socialization by the government on several issues, low public trust in the government, to the ineffectiveness of government communication between institutions. The Indonesian government has issued many public policies, which in the end confuses the public with the many synchronized policies issued.

\subsection{Local Government Response}

Through the Ministry of Health, the Indonesian government responded to the state of public health emergency of international concern due to $2019-\mathrm{nCoV}$ infection by assigning several control measures that health authorities should take at the national, province, or district/city level. The government formally regulated the control measure through a ministerial decree issued in February 2020, while no cases had been reported in Indonesia. The responsibilities of the governments stated in the decree included improving the communication, information, and education to the community, particularly those who planned to travel to high-risk places; the preparedness and early detection in the entrance area; health care capacity, laboratories, and referral system; and inter-sector coordination.

Responding to the state of emergency of the COVID19 pandemic and following the identification of the first case of COVID-19 in Indonesia, the central government established a national task force to handle the COVID-19 pandemic through inter-sector involvement. The Task Force for the Acceleration of the Response to COVID-19 was formed in March 2020 to improve the national health system, accelerate the government response, anticipate COVID-19 escalation, and make operational decisions. Then, the subnational government (provincial and district/city) was required to establish a similar task force at the local level.

The governor of West Sumatra Province responded to the decree by issuing an official letter on 16th March 2020 stating that the local government leaders agreed to take prompt preventive and control measures since no COVID-19 case was reported at the time. They coincided with establishing the COVID-19 Local Task Force at the province, district, or city level. In addition to establishing the task force, the local leaders would enhance the implementation of preventive protocols at public places, postpone any public meeting except a strategic plan attended by limited participants, and deliver official information regarding the pandemic situation in the province. Particularly in Padang City, a Local COVID-19 Task Force was formed through the mayor decree 149/2020, issued on 27th March 2020. This regulation underlined the organization, responsibilities, coordination mechanism, and financing of the task force. The role of the local task force is identical to the duties of the national task force mentioned in the presidential decree.

The Indonesian government implemented a largescale social restriction (PSBB) to restrain public mobilization rather than a total lockdown. PSBB limits certain public activities, including education, formal sectors, religious activities, social and cultural events in the high-risk province or district/city. PSBB in West Sumatera Province was implemented at all 19 districts and cities on 18th April 2020, extending to 19th May 2020. The city mayor of Padang reinforced the policy by issuing legal instruments regulating the public activities during PSBB. City regulations regarding PSBB included the arrangement of PSBB in Padang City, the decree on penalties for any violation during PSBB, and a law on the restriction of domestic travels out or into Padang City.

The negative impact of PSBB on social and economic aspects in Indonesia led the government to discontinue the implementation of PSBB. The government adopted a micro-level of public activities restriction (PPKM). PPKM differed from PSBB in terms of the flexibility of social limitations. The government could decide to implement PPKM in a certain subdistrict, village, office, or even neighborhood only rather than the whole area of a district or city during PSBB to minimize more significant economic and social impact. However, occasional restrictions related to specific public events were still maintained in PPKM, such as shortening religious celebrations days and national holidays. The Ministry of Transportation also contributed by issuing 
several regulations to be implemented nationally regarding domestic and international travel requirements for all modes of transport.

The government of Padang City showed a quick response in issuing local regulations during the implementation of PPKM. Since the PPKM was initiated in April 2021, the Ministry of Health $(\mathrm{MoH})$ categorized Padang City several times at level four (the highest level). The local regulation arranged education activities at school and educational institutions, working arrangements for formal sectors, the operational time of restaurants and other public facilities, travel procedures, and other public events. The lower the level of PPKM, the more activities are allowed.

The government of Indonesia called new-normal for a new life with the adaptation of behavioral change since the emergence of COVID-19 following the official statement from $\mathrm{MoH}$ regarding national movement on prevention protocols of COVID-19, including mask use, washing hand, and physical distancing. Then, the terms of adaptation of behavioral change (Adaptasi Kebiasaan Baru, AKB) were first stated in the official letter of the Minister of Religion, which regulates the religious activities during the pandemic in May 2020. Adopting prevention protocols in public activities was then encouraged to reduce COVID-19 morbidity and mortality and economic recovery. West Sumatera government responded to this initiative by issuing a regulation of the AKB in COVID-19 prevention and control on 30th September 2020, following the provincial law on travel supervision out from and into West Sumatera. The local house of legislative issued the derivative regulation on AKB in Padang City on 7th January 2021. As the PPKM has been implemented, more public activities are opened, and the law of $\mathrm{AKB}$ is relevant to guide the communities in COVID-19 prevention during their daily movements.

The pandemic of COVID-19 challenges the function of local government to maintain the people's health, particularly in Indonesia, with 34 provinces spread in more than 17,000 islands. In a country such as Indonesia, strengthening inter-sector coordination and improving local government capacity are two essential strategies in addressing an extreme disaster such as the COVID-19 pandemic. The subnational or local government is at the forefront for COVID-19 control in a country with a decentralized governmental system. Therefore, decisionmaking and regulation-making are crucial to the legal justification for the program financing and resource allocation.

The local government of the City of Padang showed a quick response in terms of regulation-making. The local regulations are issued immediately once the national law is acted. The local law arranged the unit in-charged of each program for pandemic control, the organization, the responsibilities of each structure, the coordination mechanism, and the financing arrangement.

The regulation issued by the city government covers the whole aspects of public needs and activities. It included education, transportation, social and religious events. There were also regulations in the health sector, including improving tracking, testing, treatment, expanding vaccination coverage, and the resource allocation for COVID-19 control. In terms of mitigating the impact of a pandemic, the local regulations covered government subsidies for the communities and informal sectors.

\section{Conclusions}

The study has shown that the Government of Indonesia has responded to COVID-19 pandemics by issuing many regulations at the national and local levels. The regulations are $30 \%$ related to social society, $10 \%$ related to the budget, $25 \%$ related to health, $20 \%$ related to organizations handling COVID- 19 , and $15 \%$ related to economic recovery. The local government has responded quickly with the national regulation by issuing a local regulation at the province, district, and city-level as legal justification for resource allocation.

The challenges on implementing those regulations are the slow initial response by the government, fulfillment of the community's economic needs, weak coordination between stakeholders, community non-compliance, culture and politics, and ineffective public information.

This paper is a preliminary review of an ongoing study. To understand how health factors can be embedded into disaster risk reduction, a series of interviews are being conducted with key officials from the National Disaster Management Agency (BNPB), the COVID-19 taskforce, and the Ministry of Health. It is also planned that direct observations will be made to locations that are experiencing disasters during the COVID-19 pandemic; and also planned a series of focused group discussions with key stakeholders in the city of Padang.

The authors would like to thank the Newton Fund Institutional Link British Council for funding this research, which collaborates between the Universitas Andalas (Indonesia) and the University of Huddersfield (UK). Universitas Andalas is funded by the Basic Partnership Research (RKD) scheme from the Ministry of Education, Culture, Research, and Technology with a derivative contract number T/2/UN.16.17/PT.01.03/RKD-Soshum/2021.

\section{References}

1. M. Coccia, "Preparedness of countries to face a COVID-19 pandemic crisis: Strategic positioning and underlying structural factors to support strategies of prevention of pandemic threats," Environ. Res., (2021).

2. R. Djalante et al., "Review and analysis of current responses to COVID-19 in Indonesia: Period of January to March 2020," Prog. Disaster Sci. 6, p. 100091, (2020).

3. B. W. Kulohoma, "COVID-19 risk factors: The curious case of Africa's governance and preparedness," Sci. African, 13, p. e00948, (2021).

4. B. M. Vallejo Jr and R. A. C. Ong, "Policy responses and government science advice for the COVID 19 pandemic in the Philippines: January to April 2020," Prog. disaster Sci., 7, p. 100115, (2020). 
5. WHO, "Indonesian Situation," 2021. https:/COVID19.who.int/region/searo/country/id (accessed 22nd August 2021).

6. Indonesian COVID-19 Taskforce, "Distribution Map," 2021. https://COVID19.go.id/peta-sebaran (accessed 22nd August 2021).

7. Diskominfo Padang, "Padang City Condition," 2021. http://corona.padang.go.id (accessed Aug. 22, 2021).

8. Indonesian COVID-19 Taskforce, "Risk Map," 2021. https://COVID19.go.id/peta-risiko (accessed 22nd August 2021).

9. L. K. Alfirdaus and T. Yuwono, "Pandemi COVID19 dan Pendekatan Kebijakan Multikrisis: Sebuah Refleksi Teoritis," JIIP J. Ilm. Ilmu Pemerintah., 5, 2, 206-216, (2020).
10. A. A. Sitorus, " Synchronized Indonesian Government Policies in Handling COVID-19," J. Renaiss., 6, 1, 721-732, (2021).

11. Z. Harirah and A. Rizaldi, " Responding to State Policy Reasons in Dealing with the COVID 19 Pandemic in Indonesia," J. Econ. and Policy. Indonesian public., 7, 1, (2020).

12. S. Mujani and D. Irvani, " Citizens' Attitudes and Behaviors towards Policies for Handling the COVID19 Outbreak," Polit. J. Ilmu Polit., 11, 2, 219-238, (2020).

13. L. Agustino, "a Analysis Of COVID-19 Outbreak Handling Policy: The Experience Of Indonesia," Junal Borneo Adm., 16, 2, 253-270, (2020). 